\title{
CORRESPONDENCE
}

\author{
TO THE EDITOR OF THE Journal of Philosophical Studies.
}

DeAr Sir,

I cannot, in the brief space of a letter, vindicate my book, The Meaning of Beauty, against Mr. R. G. Collingwood's attack in his review in the July issue. May I, however, be allowed to make a few comments?

Criticism, of course, I expect, and have naturally received in other journals. But in no single case, except Mr. Collingwood's, have I risen from reading a review with the unsavoury feeling that the reviewer was definitely lacking in the intention to be fair and just. In all other serious reviews I have felt that the critic had attempted an impartial appraisement both of what he thought to be the defects and the merits of the book. Mr. T. E. Jessop's review in the January issue of Mind was a good example. Mr. Collingwood's tone is hostile, and even contemptuous. His review occupies over two thousand words, the whole of which is devoted to picking holes. There is not a single sentence acknowledging a solitary merit in the book. It reads as if he had sat down, not with the wish to balance pros and cons, and to judge impartially, but rather saying to himself, "How can I most effectively damn this book?"

The reviewer says: "Mr. Stace . . confesses that he has no idea what Croce means by æesthetic form." I have confessed no such thing, and this is a complete, and no doubt intentionally damaging, distortion of my words. The view expressed by me was that Croce's theory of intuition as a form of cognition is meaningless ("cannot be rationally comprehended" are my words). This may be true or false, but it is not a confession that I do not understand Croce. Mr. Collingwood knows this quite well, and yet he represents it as such, omitting to quote my words. It is difficult to attach the correct adjective to such methods of criticism.

It appears that in one sentence on music in my book the word bass is misprinted base. Would any fair-minded critic be so petty as to make capital of this? Yet Mr. Collingwood does. "The musician," he says, "if he can bring himself to be civil to a person who writes base when he means bass. . . " I will pass from your reviewer's sneers and misrepresentations to his efforts at serious criticism. His first point is that $I$ have not made clear the distinction between perceptual and non-perceptual concepts, so that there remain doubts into which class one should place certain concepts. This is a complaint of failure to define correctly. If it is true, it is a defect in the book, and the critic is quite right to point it out. But this would not invalidate my general theory, because it is quite clear that the distinction is a real one, whether I have satisfactorily defined it or not. A reasoner's deduction from the fact that there is a distinction between lions and tigers would not be invalidated by his inability to give zoological or anatomical definitions of the species. So here. You perceive a man as a man. You can never perceive him as an evolved being. There is a clear distinction between the kind of concept which is embedded in sense-perception and the kind which is not.

Your critic's next argument is that it is inconsistent to hold, on the one hand that the concept is fused with the percept in the artist's mind, and yet, on the other, that the artist himself may not recognize it. If it is really there, "the artist ought consciously to perceive his object ... as an instance of the concept. ... If it is not, the whole theory falls to the ground." Not at all. Some artists may be fully conscious of the inner meaning (concept) of their work. With others it is more or less unconscious. This is common, not only with artists, but with all men. Mr. Collingwood is merely scratching up again the old supposed contradiction involved in unconscious thought. I advise him to study the passages in M. Wyndham Lewis's Paleface, which discuss the work of D. H. Lawrence, and show how that author 


\section{JOURNAL OF PHILOSOPHICAL STUDIES}

meant, and was clearly driving at philosophical concepts of which he was undoubtedly unconscious.

Finally, the reviewer inquires "how are we to know that the philosopher has extricated the right concept" from the work of art? I answer that one can only know by using one's gumption. There is certainly no royal road here, and if your critic's complaint is that I have not supplied a fool-proof formula for understanding the meanings of all works of art, I admit it. How does Mr. Wyndham Lewis know that D. H. Lawrence meant and thought so and so? I have not the faintest idea. But I know that the man of fine perceptions is likely to agree with Mr. Wyndham Lewis, while the fool will remain out in the dark.

Yours very truly,

W. T. Stace.

\section{Colombo, Cerlon,} July 22, 1930. 